\title{
THE INFLUENCE OF ACCOUNTABILITY AND TRANSPARENCY OF FINANCIAL MANAGEMENT OF VILLAGE FUNDS ON VILLAGE GOVERNMENT PERFORMANCE IN KOTARIH BARU VILLAGE KOTARIH DISTRICT SERGAI REGENCY
}

\author{
Suriana ${ }^{1}$ \\ ${ }^{1}$ Faculty of Economics UNIVA MEDAN \\ Correspondence Author: suriana7771@gmail.com
}

\begin{abstract}
This study aims to determine whether accountability and transparency in the financial management of village funds, either partially or simultaneously, have a significant effect on the performance of village government in Kotarih Baru Village, Kotarih District, Sergai Regency and how big the effect is. The method used in this study is a quantitative method with several tests, namely reliability analysis, classical assumption deviation test and linear regression. Based on the results of the primary data regression which was processed using SPSS 20, the following multiple linear regression equation was obtained: $Y=6.578+0.415 X 1+0.438 X 2$.Partially, the accountability variable (X1) has a significant effect on the performance of village government in Kotarih Baru Village, Kotarih District, Sergai Regency. This means that the hypothesis in this study is accepted, as evidenced by the value of $t$ count $>t$ table $(2,143>2,037)$. While the variable of financial management transparency of village funds (X2) has a significant influence on the performance of village government in Kotarih Baru Village, Kotarih District, Sergai Regency. This means that the hypothesis in this study is accepted, as evidenced by the value of $t$ count $>t$ table $(2.173>2,037)$. Simultaneously, the accountability variable $(X 1)$ and the transparency of village fund financial management (X2) have a significant influence on the performance of village government in Kotarih Baru Village, Kotarih District, Sergai Regency. This means that the hypothesis in this study is accepted, as evidenced by the calculated $F$ value > F table (18,489 > 3.29). The accountability variable (X1) and the transparency of village fund financial management (X2) are able to contribute to the influence of the village government performance variable by $53.6 \%$ while the remaining $46.4 \%$ is influenced by other variables not examined in this study.
\end{abstract}

Keywords : Accountability, Transparency, and Village Government Performance

\section{INTRODUCTION}

In the current government system, villages/kelurahan have a strategic role in assisting local governments in the process of governance, including development. All of this is done as a real step for the local government to support the implementation of regional autonomy in their territory. The implementation of autonomy for the village will be a force for the village government to manage, regulate and organize its own household, as well as increase the burden of village responsibilities and obligations, however, the administration of the government must still be accounted for. The accountability in question includes accountability in managing the village budget.

The achievement of government performance and stability of development as well as economic equity is not only oriented at the national and regional levels but also needs to pay attention to the lowest government area in this case is the village which is one of the administrative areas that regulates its own government affairs. When organizing government, community service and development, the government carries out three main functions, namely the allocation function which includes between economic resources in the form of goods and public services, the distribution function which includes, among others, community income and wealth, equitable development and stabilization function. 
The Influence of Accountability and Transparency of Financial Management of Village Funds on Village Government Performance in Kotarih Baru Village Kotarih District Sergai Regency

Suriana

In this case, accountability is one of the supporting aspects of government performance. After the enactment of Law No. 34 of 2014 concerning Central and Regional Financial Balance, the regional authority to manage financial resources is a process to encourage development in the region and will further encourage accountable national development processes. Government authority delegated to the regions in the context of decentralization must be accompanied by the transfer and transfer of financing, facilities and infrastructure, and human resources in accordance with the delegated authority. Government financial reports must provide information that can be used by users of financial statements to assess government accountability in making economic, social and political decisions. Accountability is defined as the relationship between the party who controls and regulates the entity and the party that has formal power over the controlling party. In this case, an accountable third party is also needed to provide an explanation or reasonable reason for all activities carried out and the business results obtained in connection with the implementation of a task and the achievement of a certain goal and of course avoiding fraud.

In addition to accountability, another aspect that greatly impacts government performance is transparency. Transparency is the openness of the government in making regional financial management, so that it can be known and monitored by the DPRD and the community. Transparency in regional financial management will ultimately create horizontal accountability between local governments and their communities, so as to create clean, effective, efficient, accountable, and responsive local governments to the aspirations and interests of the community. In this case, the government will be considered to have good performance related to its function.

Kotarih District is one of the 17 sub-districts in Serdang Bedagai Regency, and is a regional apparatus of Serdang Bedagai Regency in accordance with RI Law Number 32 of 2004 concerning regional government and Law Number 36 of 2003 concerning the establishment of Serdang Bedagai Regency.The challenge of managing village funds to improve community welfare and appropriate beneficiaries to support financial performance in the public sector is deemed necessary and implemented by villages in Serdang Bedagai district. The village government in managing finances must make the best possible use of the village needs that have been prioritized from the original planning. This of course has been done by the village government which then refers to the PP Law No. 14 of 2014. But of course there are obstacles related to the performance of the village government including the implementation of budget management that has not been effective and efficient, because the problem is that in the implementation there are obstacles - obstacles in managing village funds caused by budget estimates by not specifying as well as possible what will be planned.

Meanwhile, related to accountability, it was found that the village government in Kotarih Baru Village, Kotarih District, Sergai Regency was still not optimal in carrying out accountability. This is because the community is still not fully aware of this responsibility. So that every financial management is not known by the public. In addition, other problems identified from the transparency aspect can be seen in the aspect of the village government's lack of attention in openness to the community when planning the management of village funds so that sometimes what is designed does not work optimally, in this case it will have an impact on public trust in the authorities. in the village. Transparency problems also occur in the planning process village financial management where the community is not involved in planning, even though the involvement or participation in the budget will have an impact on the decline. Based on the explanation above, the researchers chose to conduct a study entitled "The Effect of Accountability and Transparency of Village Fund Financial Management on Village Government Performance in Kotarih Baru Village, Kotarih District, Sergai Regency".

\section{IMPLEMENTATION METHOD}

\subsection{Population and Sample}

The population is the whole object of research and fulfills certain characteristics. According to Sekaran and Bougie (in Syaiful, 2018: 49) the population is a group of people, events, or 
interesting things and then the researcher wants to investigate and make an opinion. According to Cooper and Emory (in Syaiful, 2018: 49) the population is the entire collection of elements that can be used to make some conclusions. The population in this study are all employees who work in Kotarih Baru Village, Kotarih District, Sergai Regency, totaling 35 people.

The sample is part of the population taken through certain ways which also have certain characteristics. Samples will be taken if the researcher is not able to conduct research by taking data directly from the population (Efferin, in Syaiful, 2018: 51). According to Furchan (in Syaiful, 2018: 51) the sample is part of the population, or a small group being observed. Given the small number of population, namely 35 people, the authors use all the population as respondents with a saturated sampling technique (census), so the sample in this study was 35 people.

\subsection{Data Types and Sources}

Sugiyono (2017:102) states that because in principle research is to take measurements, there must be a good measuring instrument. Measuring tools in research are usually called research instruments. So the research instrument is a tool used to measure the observed natural and social phenomena. Specifically, all of these phenomena are called research variables. In this study, primary data and secondary data were used.

Types and sources of data used in this study include:

a. Primary Data

Sugiyono (2017:137) states "Primary data sources are data sources that directly provide data to data collectors". Primary data is data that can be obtained directly and immediately from the source, in this case the data obtained from the questionnaire used and filled in by the respondent containing questions.

b. Secondary Data

Sugiyono (2017:137) states that secondary data sources are sources that do not directly provide data to data collectors. Secondary data is data obtained from sources other than respondents. Secondary data is data that was first collected and reported by parties other than researchers.

\subsection{Data collection technique}

Sugiyono (2017:137) states "Data collection techniques are the accuracy of the methods used to collect data that can be done in various settings, various sources, and in various ways". The data collection techniques used by researchers to obtain the necessary data and information are as follows:

\section{a. Live Observation}

Syaiful (2018: 87), direct observation is a data collection technique by researchers by making direct observations of the research object. This observation is applied to subjects/objects that are difficult to predict.

b. Interview

Syaiful (2018: 89), interview is a data collection technique by using questions to the research object. The results of these interviews are recorded and will become research data. Interview technique can be done if the research sample is small. Interviews can be grouped into two categories, namely face-to-face interviews, and interviews through tools.

c. Questionnaire

Sugiyono (2017:142) states "Questionnaire is a data collection technique that is done by giving a set of questions or written statements to respondents to answer". A method of collecting data by providing or distributing a list of questions to respondents. By using a Likert scale as a measurement. 
The Influence of Accountability and Transparency of Financial Management of Village Funds on Village Government Performance in Kotarih Baru Village Kotarih District Sergai Regency

Table 3.2.

Likert Scale

\begin{tabular}{|c|l|c|}
\hline No. & \multicolumn{1}{|c|}{ Alternative Answer } & Score \\
\hline 1. & Strongly agree & 5 \\
\hline 2. & Agree & 4 \\
\hline 3. & Disagree & 3 \\
\hline 4. & Do not agree & 2 \\
\hline 5. & Strongly Disagree & 1 \\
\hline
\end{tabular}

Source: Sugiyono, 2017

\subsection{Data analysis technique}

The data analysis technique that will be used by the author in this study is using SPSS version 18 software with statistical techniques. Statistics play an important role in research, both in modeling, in formulating hypotheses, in developing data collection tools and instruments, in preparing research designs, in determining samples, and in data analysis. Some of the statistical techniques used to analyze the data in this study are:

1. Construct Test

a. Validity test

Validity test is a measure that shows the level of validity or validity of an instrument (Arikunto, in Syaiful, 2018: 105). The questions in the questionnaire are measuring instruments (tools) that must measure what the research objectives are so that each question item in the questionnaire must be measured for validity.

b. Reliability Test

Syaiful (2018: 117), the reliability test is used to determine the consistency of the measuring instrument that uses a questionnaire. The goal is to assess whether the measurements used remain consistent if the measurements are repeated. A reliable measuring instrument has a high level of reliability which is determined by a number called the reliability coefficient ranging from $0-1$. The higher the reliability coefficient, which is close to number one, the more reliable the measuring instrument is. The reliability test technique that will be used in this study is Cronbach's Alpha.

$$
\begin{gathered}
r_{11}=\left[\frac{k}{k-1}\right]\left[1-\frac{\sum \sigma_{i}^{2}}{\sigma_{t}^{2}}\right] \\
\sigma_{1}^{2}=\frac{\sum X^{2}-\frac{\left(\sum X\right)^{2}}{n}}{n}
\end{gathered}
$$

Where :

$$
\begin{array}{ll}
\mathrm{r}_{11} & =\text { instrument reliability } \\
\mathrm{k} & =\text { number of respondents } \\
\mathrm{n} & =\text { number of respondents } \\
\sum \sigma_{i}^{2} & =\text { number of item variables } \\
\sum \sigma_{t}^{2} & =\text { squared variance }
\end{array}
$$

Then to find out the high and low reliability values in this study, the reliability results were consulted with the interpretation table of $r$ values, as follows: 
Table 3.3.

Interpretation of the Value of $r$

\begin{tabular}{|c|c|}
\hline The value of $\mathbf{r}$ & Interpretation \\
\hline $0.81-1.00$ & Very high \\
\hline $0.61-0.80$ & Tall \\
\hline $0.41-0.60$ & Currently \\
\hline $0.21-0.40$ & Low \\
\hline $0.00-0.20$ & Very low \\
\hline
\end{tabular}

Source: Arikunto (2016, p. 18)

2. Classical Assumption Deviation Test

According to Duwi Priyatno (2008:151), "The classical assumption deviation test is used to determine the presence or absence of multicollinearity, autocorrelation and heteroscedasticity in the regression model".

a. Multicollinearity Test

Duwi Priyatno (2008:152), states that: "Multicollinearity means that the independent variables contained in the regression model have a perfect or near perfect linear relationship (the correlation coefficient is high or even 1). A good regression model should not have a perfect or near perfect correlation between the independent variables. The consequence of multicollinearity is that the correlation coefficient of an indeterminate variable becomes very large or infinite.

b. Autocorrelation Test

Duwi Priyatno (2008:158), states that: "Autocorrelation is a correlation between members of observations arranged according to time or place. A good regression model should not have autocorrelation.

c. Heteroscedasticity Test

Duwi Priyatno (2008: 160), states that: "Heteroscedasticity is the residual variance that is not the same for all observations in the regression model. A good regression should not occur heteroscedasticity".

d. Normality test

Duwi Priyatno (2008: 160), states that: "The normality test is used to determine whether the data population is normally distributed or not. This test is usually used to measure data on an ordinal, interval, or ratio scale.

3. Linear Regression

According to Duwi Priyatno (2008:127), "Linear regression is a linear relationship between independent variables used to predict or predict a dependent variable value based on independent variables". In this study, the tests that will be carried out for regression analysis are as follows:

a. Multiple Linear Regression Analysis

Duwi Priyatno (2008:137), states that: "Multiple linear regression analysis is useful for analyzing the linear relationship between 2 or more independent variables with 1 dependent variable".

The regression equation is as follows:

$$
\mathrm{Y}=\mathrm{a}+\mathrm{b} 1 \mathrm{X} 1+\mathrm{b} 2 \mathrm{X} 2+\mathrm{e}
$$

Information:

$\mathrm{Y} \quad=$ Dependent Variable (Village Government Performance)

a $=$ Constant Value

b1X1 = Value of Variable Regression Coefficient X1 (Accountability) 
The Influence of Accountability and Transparency of Financial Management of Village Funds on Village Government Performance in Kotarih Baru Village Kotarih District Sergai Regency

Suriana

$$
\begin{aligned}
& \text { b2X2 = Value of Variable Regression Coefficient X2 (Transparency } \\
& \text { Village Fund Management) } \\
& \mathrm{e}=\text { Standard Error }
\end{aligned}
$$

b. $t$ test

Duwi Priyatno (2008:147), states that: "The t-test or t-count is a significance test to find out the effect of the X1 and X2 variables on Y partially, whether it has a significant effect or not. To find out whether the results are significant or not, the t-count will be compared with the t-table.

Test criteria:

If $\mathrm{t}$ count $>\mathrm{t}$ table in 2 -sided test with sig. 0.05 then it is declared to have a significant effect.

If $\mathrm{t}$ count $<\mathrm{t}$ table on 2 -sided test with sig. 0.05 then declared no significant effect.

c. F Uji test

Duwi Priyatno (2008:146), states that: "ANOVA or analysis of variance is a regression coefficient test together ( $\mathrm{F}$ test) to test the significance of the influence of several independent variables on the dependent variable". To find out whether the result is significant or not, the calculated F number will be compared with the F table.

Test criteria:

If $\mathrm{F}$ count $>\mathrm{F}$ table on 2 -sided test with sig. 0.05 then it is declared to have a significant effect.

If $F$ count $<F$ table on 2 -sided test with sig. 0.05 then declared no significant effect.

d. Coefficient of Determination Test (R2)

Duwi Priyatno (2008:144), states that: "R Square or the square of $R$ shows the coefficient of determination. This figure will be converted into a percent, meaning the percentage contribution of the influence of the independent variable on the dependent variable".

\subsection{Variable Operational Definition}

\begin{tabular}{|c|c|c|c|}
\hline $\begin{array}{l}\text { Research } \\
\text { variable }\end{array}$ & $\begin{array}{c}\text { Definition } \\
\text { Variable }\end{array}$ & Variable Indicator & $\begin{array}{c}\text { Measuring } \\
\text { Scale }\end{array}$ \\
\hline $\begin{array}{c}\text { Accountabilit } \\
\text { y (X1) }\end{array}$ & $\begin{array}{l}\text { Accountability is an instrument } \\
\text { for control activities, especially } \\
\text { in achieving results in public } \\
\text { services. In this connection, it is } \\
\text { necessary to conduct a } \\
\text { performance evaluation to find } \\
\text { out the extent to which the } \\
\text { results are achieved and the } \\
\text { methods used to achieve all of } \\
\text { them, Nasirah (2016) }\end{array}$ & $\begin{array}{c}\text { Planning Stage } \\
\text { Reporting Stage } \\
\text { Accountability Stage }\end{array}$ & $\begin{array}{l}\text { Scale } \\
\text { Likert }\end{array}$ \\
\hline $\begin{array}{l}\text { Transparency } \\
\text { of Village } \\
\text { Fund } \\
\text { Financial } \\
\text { Management } \\
\text { (X2) }\end{array}$ & $\begin{array}{l}\text { According to Andrianto (2007), } \\
\text { transparency is an openness that } \\
\text { is truly, comprehensive, and } \\
\text { provides a place for active } \\
\text { participation from all levels of } \\
\text { society in the process of } \\
\text { managing public resources. }\end{array}$ & $\begin{array}{l}\text { Whether or not there } \\
\text { is a legal framework } \\
\text { for transparency } \\
\text { There is public } \\
\text { access to budget } \\
\text { transparency } \\
\text { There is an }\end{array}$ & $\begin{array}{l}\text { Scale } \\
\text { Likert }\end{array}$ \\
\hline
\end{tabular}

Table 3.4

Variable Operational Definition 


\begin{tabular}{|c|c|c|c|}
\hline & $\begin{array}{c}\text { Every policy issued by the } \\
\text { organizer must be accessible } \\
\text { openly by providing sufficient } \\
\text { space for the public to participate } \\
\text { widely in it }\end{array}$ & $\begin{array}{l}\text { independent and } \\
\text { effective audit } \\
\text { Community } \\
\text { involvement in } \\
\text { budget decision } \\
\text { making }\end{array}$ & \\
\hline $\begin{array}{c}\text { Village } \\
\text { Government } \\
\text { Performance } \\
\quad \text { (Y) }\end{array}$ & $\begin{array}{l}\text { According to Simanjuntak in } \\
\text { Sutrisno performance is "the } \\
\text { level of achievement of results } \\
\text { on the implementation of certain } \\
\text { tasks". Improving the } \\
\text { performance of an organization } \\
\text { can be done by improving the } \\
\text { performance of each individual. } \\
\text { The term worker comes from the } \\
\text { word job performance or actual } \\
\text { performance, namely work } \\
\text { performance or actual } \\
\text { achievement achieved by } \\
\text { someone. }\end{array}$ & $\begin{array}{l}\text { Productivity } \\
\text { Service Quality } \\
\text { Responsiveness } \\
\text { Responsibility } \\
\text { Accountability }\end{array}$ & $\begin{array}{l}\text { Scale } \\
\text { Likert }\end{array}$ \\
\hline
\end{tabular}

\section{RESULTS AND DISCUSSION}

\subsection{Reliability Analysis}

Reliability Analysisintended to obtain good and quality research results. Reliability Analysis is divided into 2 tests, namely the validity test and the reliability test. Validity and reliability tests were carried out on research tools, in this case a questionnaire. Valid means that the data obtained by using tools (instruments) can answer the research objectives, while reliable means that they are consistent and stable.

a. Validity test

Table 4.5.

Results Validity test

\begin{tabular}{|c|c|c|c|c|}
\hline $\begin{array}{c}\text { Research } \\
\text { variable }\end{array}$ & Question Items & r count & r table & Note: \\
\hline \multirow{5}{*}{$\begin{array}{c}\text { The stages of budget management } \\
\text { involve elements of the community }\end{array}$} & 0.614 & 0.333 & Valid \\
\cline { 2 - 6 } & $\begin{array}{c}\text { The budget is presented openly, } \\
\text { quickly, and accurately to the whole } \\
\text { community }\end{array}$ & 0.537 & 0.333 & Valid \\
\cline { 2 - 6 } & $\begin{array}{c}\text { Public and group interests are the } \\
\text { main concern and consideration in } \\
\text { Accountability } \\
\text { (X1) }\end{array}$ & 0.509 & 0.333 & Valid \\
\cline { 2 - 6 } & $\begin{array}{c}\text { The budget is a secret document so } \\
\text { the public does not need to know }\end{array}$ & 0.739 & 0.333 & Valid \\
\cline { 2 - 6 } & $\begin{array}{c}\text { Indicators of performance results to } \\
\text { be achieved are set and have been } \\
\text { used to evaluate the budget }\end{array}$ & 0.647 & 0.333 & Valid \\
\cline { 2 - 6 } & $\begin{array}{c}\text { Budget processes and accountability } \\
\text { are monitored continuously }\end{array}$ & 0.655 & 0.333 & Valid \\
\cline { 2 - 6 } & $\begin{array}{c}\text { The budget presentation has included } \\
\text { past information }\end{array}$ & 0.628 & 0.333 & Valid \\
\hline
\end{tabular}

International Journal of Educational Review, Law And Social Sciences |IJERLAS 
The Influence of Accountability and Transparency of Financial Management of Village Funds on Village Government Performance in Kotarih Baru Village Kotarih District Sergai Regency

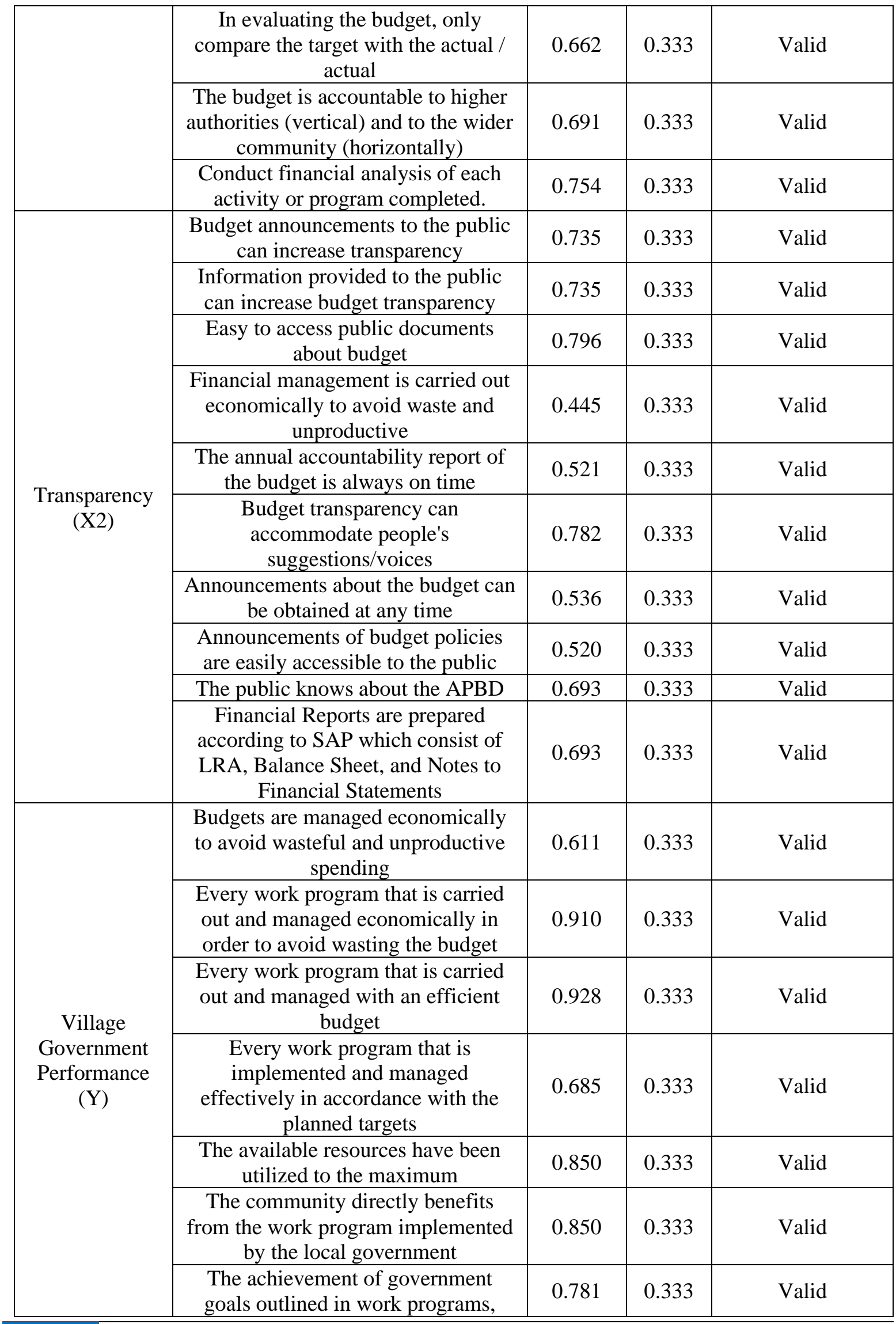




\begin{tabular}{|c|c|c|c|c|}
\hline & activities and policies has reached & & & \\
\cline { 2 - 5 } & $\begin{array}{c}\text { There than } 80 \% \\
\text { to fight for regional aspirations and } \\
\text { interests }\end{array}$ & 0.611 & 0.333 & Valid \\
\cline { 2 - 5 } & $\begin{array}{c}\text { The budget is always used efficiently } \\
\text { and economically in every activity }\end{array}$ & 0.910 & 0.333 & Valid \\
\cline { 2 - 5 } & $\begin{array}{c}\text { The targeted program can achieve the } \\
\text { set results }\end{array}$ & 0.928 & 0.333 & Valid \\
\hline
\end{tabular}

Source: Research Results 2021 (Data Processed)

b. Reliability Test

Table 4.6.

Reliability Test Results

\begin{tabular}{|c|c|c|c|}
\hline Research variable & $\begin{array}{c}\text { Number of } \\
\text { Questions }\end{array}$ & Cronbach's Alpha & Result Description \\
\hline $\begin{array}{c}\text { Accountability } \\
\text { (X1) }\end{array}$ & 10 & 0.895 & Well \\
\hline $\begin{array}{c}\text { Transparency } \\
\text { (X2) }\end{array}$ & 10 & 0.892 & Well \\
\hline $\begin{array}{c}\text { Village } \\
\text { Government } \\
\begin{array}{c}\text { Performance } \\
\text { (Y) }\end{array}\end{array}$ & 10 & 0.956 & Well \\
\hline
\end{tabular}

Source: Research Results 2020 (Data Processed)

According to Uma Sekaran (in Priyatno, 2008:172), "Reliability less than 0.6 is not good, while 0.7 is acceptable and above 0.8 is good". From the table above, it can be seen that the value ofCronbach's Alpha for each variable can be said to be reliable or in good condition.

\subsection{Classical Assumption Deviation Test}

a. Normality test

Normality test is a test carried out with the aim of assessing the distribution of data in a group of data or variables, whether the distribution of the data is normally distributed or not. Normality test is useful for determining the data that has been collected is normally distributed or taken from a normal population. The classical method of testing the normality of a data is not so complicated. 
The Influence of Accountability and Transparency of Financial Management of Village Funds on Village Government Performance in Kotarih Baru Village Kotarih District Sergai Regency

Table 4.7.

Normality Test Results

One-Sample Kolmogorov-Smirnov Test

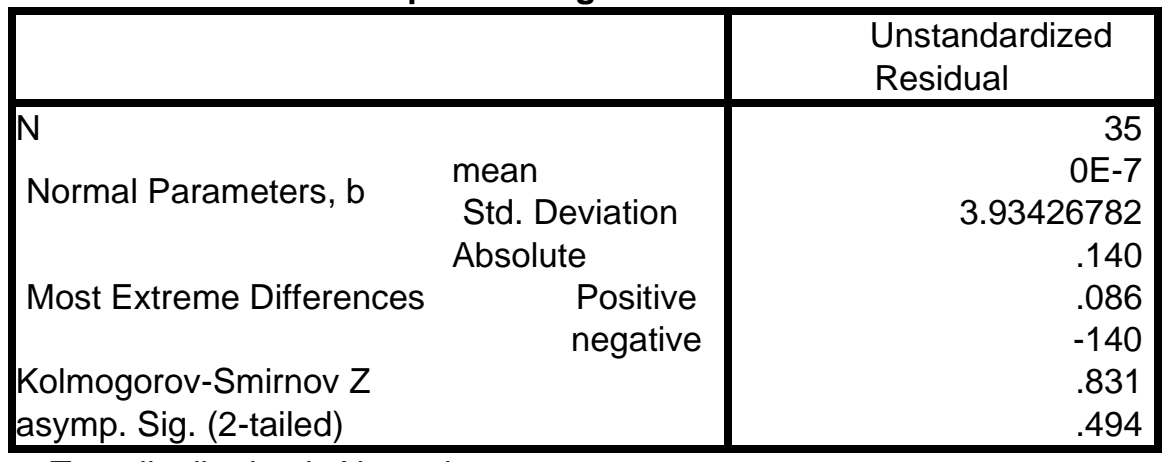

a. Test distribution is Normal.

b. Calculated from data.

Source: SPSS Version 20 Output, Data Processed 2021

From the table of normality test results above, it is known that the significance value of 0.494 is greater than 0.05 so it can be concluded that the tested data is normally distributed.

\section{b. Multicollinearity Test}

Multicollinearity isa situation that shows a strong correlation or relationship between two or more independent variables in a multiple regression model. If there is multicollinearity, then a variable that is strongly correlated with other variables in the model, the predictive power is unreliable and unstable, and the meaning of multicollinearity actually lies in the presence or absence of correlation between independent variables.

Table 4.8.

Multicollinearity Test Results

Coefficientsa

\begin{tabular}{|c|c|c|c|c|c|c|c|}
\hline \multirow[t]{2}{*}{ Model } & \multicolumn{2}{|c|}{$\begin{array}{c}\text { Unstandardized } \\
\text { Coefficients }\end{array}$} & $\begin{array}{l}\text { Standardized } \\
\text { Coefficients }\end{array}$ & \multirow[t]{2}{*}{$\mathrm{t}$} & \multirow[t]{2}{*}{ Sig. } & \multicolumn{2}{|c|}{$\begin{array}{l}\text { Collinearity } \\
\text { Statistics }\end{array}$} \\
\hline & B & Std. Error & Beta & & & Tolerance & VIF \\
\hline (Constant) & 6.578 & 5.775 & & 1,139 & .263 & & \\
\hline${ }_{1} \begin{array}{c}\text { Accountabilit } \\
y\end{array}$ & .415 & .194 & .389 & 2,143 & .040 & .440 & 2.271 \\
\hline Transparency & .438 & .201 & .394 & 2.173 & .037 & .440 & 2.271 \\
\hline
\end{tabular}

a. Dependent Variable: Performance

Source: SPSS Version 20 Output, Data Processed 2021

From the table of multicollinearity test results above, it can be explained that the Tolerance value is $0.440>0.1$ and the VIF value is $2.271<10$. These results indicate that there is no multicollinearity in the regression model.

\section{c. Autocorrelation Test}

Autocorrelation is a correlation between observation members arranged according to time or place. A good regression model should not have autocorrelation. 
Table 4.9.

Autocorrelation Test Results

Model Summaryb

\begin{tabular}{|c|c|c|c|c|c|}
\hline Model & $\mathrm{R}$ & $\mathrm{R}$ Square & $\begin{array}{c}\text { Adjusted R } \\
\text { Square }\end{array}$ & $\begin{array}{c}\text { Std. Error of the } \\
\text { Estimate }\end{array}$ & Durbin-Watson \\
\hline 1 & $.732 \mathrm{a}$ & .536 & .507 & 4.05535 & 2.039 \\
\hline
\end{tabular}

a. Predictors: (Constant), Transparency, Accountability

b. Dependent Variable: Performance

Source: SPSS Version 20 Output, Data Processed 2021

\section{d. Heteroscedasticity Test}

Heteroscedasticity is the residual variance that is not the same in all observations in the regression model. A good regression should not occur heteroscedasticity.

Figure 4.2.

\section{Heteroscedasticity Test Results}

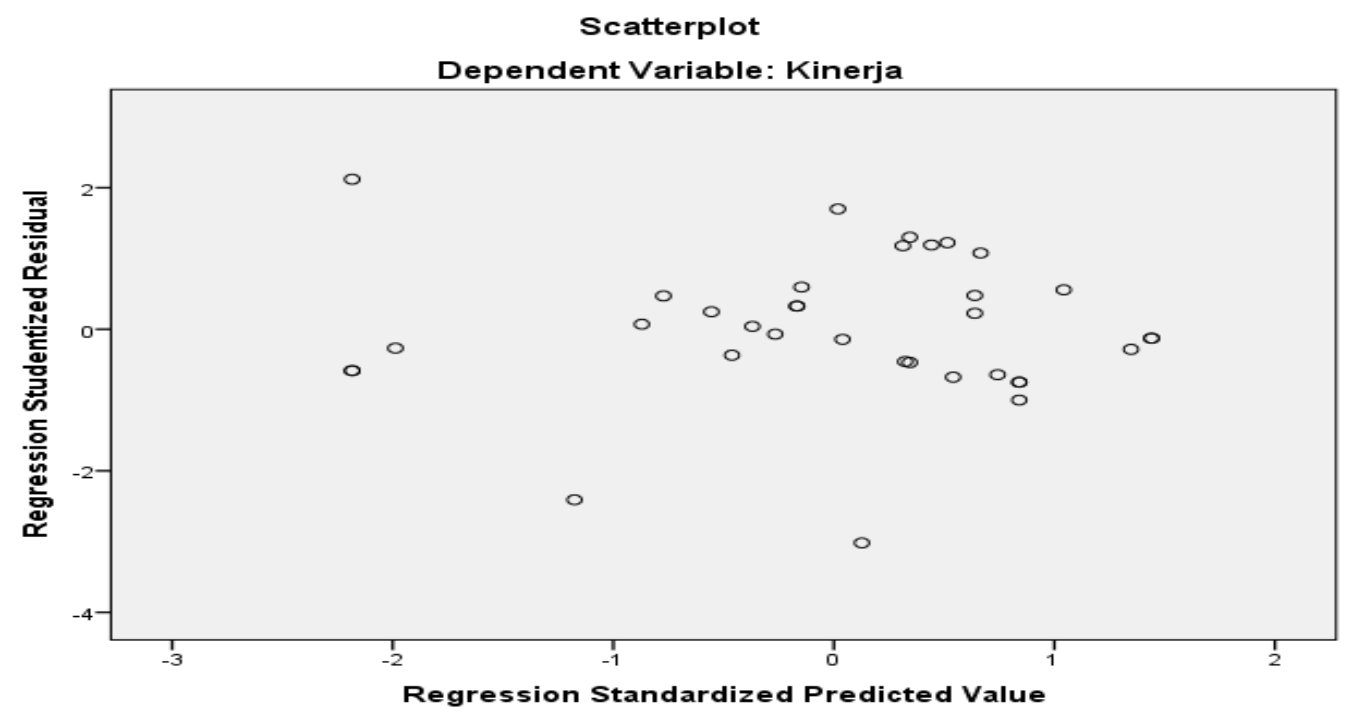

Source: SPSS Version 20 Output, Data Processed

\subsection{Linear Regression}

a. Multiple Linear Regression Analysis

Table 4.10.

Coefficientsa

\begin{tabular}{|c|c|c|c|c|c|c|c|}
\hline \multirow[t]{2}{*}{ Model } & \multicolumn{2}{|c|}{$\begin{array}{l}\text { Unstandardized } \\
\text { Coefficients }\end{array}$} & \multirow{2}{*}{$\begin{array}{c}\begin{array}{c}\text { Standardized } \\
\text { Coefficients }\end{array} \\
\text { Beta }\end{array}$} & \multirow[t]{2}{*}{$\mathrm{t}$} & \multirow[t]{2}{*}{ Sig. } & \multicolumn{2}{|c|}{$\begin{array}{l}\text { Collinearity } \\
\text { Statistics }\end{array}$} \\
\hline & B & Std. Error & & & & Tolerance & VIF \\
\hline (Constant) & 6.578 & 5.775 & & 1,139 & .263 & & \\
\hline $1{ }_{\mathrm{y}}^{\text {Accountabilit }}$ & .415 & .194 & .389 & 2,143 & .040 & .440 & 2.271 \\
\hline Transparency & .438 & .201 & .394 & 2.173 & .037 & .440 & 2.271 \\
\hline
\end{tabular}

a. Dependent Variable: Performance

Source: SPSS Version 20 Output, Data Processed 2021 
The Influence of Accountability and Transparency of Financial Management of Village Funds on Village Government Performance in Kotarih Baru Village Kotarih District Sergai Regency

The multiple linear regression equation is obtained as follows:

$$
\mathrm{Y}=6.578+0.415 \mathrm{X} 1+0.438 \mathrm{X} 2
$$

1. Constant $(\mathrm{a})=6.578$ shows a constant value, where if the variables of accountability (X1) and transparency $(\mathrm{X} 2)=0$ then the performance of the village government in Kotarih Baru Village, Kotarih District, Sergai Regency $=6,578$.

2. The regression coefficient $(\mathrm{X} 1)=0.415$ indicates that accountability has a positive effect on the performance of village government so that if accountability in Kotarih Baru Village, Kotarih District, Sergai Regency is increased by 1 unit, the village government performance will increase by 0,213 .

3. The regression coefficient $(\mathrm{X} 2)=0.438$ indicates that the transparency provided has a positive effect on the performance of the village government. So that if transparency is increased by 1 unit, the performance of the village government will increase by 0.438 .

\section{b. Partial Hypothesis Testing (t Test)}

In the Coefficientsa table, the $t$ value is also obtained. The calculated t value is then compared with the $t$ table value at $=0.05$. The value of $t$ table in $\mathrm{df}$ (nk) where $\mathrm{n}$ is the number of samples and $\mathrm{k}$ is the number of variables, both independent and dependent variables, then $35-3=32$. In df 32 with $=0.05$ the value of $t$ table is 2.037 .

The $t$ value of the accountability variable (X1) is 2143 , Thus, $t$ count $>t$ table, then $\mathrm{H} 0$ is rejected and $\mathrm{H} 1$ is accepted, which means that the accountability variable (X1) has a significant effect on the performance of village government.

The $t$ value of the village fund financial management transparency variable (X2) is 2173, Thus, $t$ arithmetic > t table, then H0 is rejected and H1 is accepted, which means that the variable of transparency in the financial management of village funds (X2) has a significant effect on the performance of village government.

c. Simultaneous Hypothesis Testing (F Test)

Table 4.11

ANOVAa

\begin{tabular}{|ll|l|l|l|c|c|}
\hline \multicolumn{1}{|c|}{ Model } & Sum of Squares & df & Mean Square & F & Sig. \\
\hline \multirow{4}{*}{1} & Regression & 608,132 & 2 & 304,066 & 18,489 & $.000 \mathrm{~b}$ \\
& Residual & 526,268 & 32 & 16,446 & & \\
& Total & 1134,400 & 34 & & & \\
\hline
\end{tabular}

a. Dependent Variable: Performance

b. Predictors: (Constant), Transparency, Accountability

Source: SPSS Version 20 Output, Data Processed 2021

In the Anovab table, the calculated $\mathrm{F}$ value is 18,489 while the $\mathrm{F}$ table value is 3.29. Thus, F count $>\mathrm{F}$ table means that the accountability and transparency variables of village financial management together have a positive and significant effect on the performance of the village government in Kotarih Baru Village, Kotarih District, Sergai Regency. 


\section{d. Coefficient of Determination Test (R2)}

Table 4.12

Model Summaryb

\begin{tabular}{|l|l|l|l|l|l|}
\hline Model & $\mathrm{R}$ & $\mathrm{R}$ Square & $\begin{array}{l}\text { Adjusted R } \\
\text { Square }\end{array}$ & $\begin{array}{l}\text { Std. Error of the } \\
\text { Estimate }\end{array}$ & Durbin-Watson \\
\hline 1 & $.732 \mathrm{a}$ & .536 & .507 & 4.05535 & 2.039 \\
\hline
\end{tabular}

a. Predictors: (Constant), Transparency, Accountability

b. Dependent Variable: Performance

Source: SPSS Version 20 Output, Data Processed 2021

The value of the coefficient of determination (R2) from the regression result is 0.536 , meaning that the accountability and transparency variables of village financial management contribute to the influence on the performance of the village government in Kotarih Baru Village, Kotarih District, Sergai District, by 53.6\%. This result is the result of ( $\mathrm{R} 2 \times 100 \%$ ), while the remaining $46.4 \%$ is influenced by other variables not examined in this study.

\section{CONCLUSION}

From the research results that have been discussed by processing questionnaire data using several tests, the following conclusions can be drawn:

1. Partially, the accountability variable (X1) has a significant effect on the performance of village government in Kotarih Baru Village, Kotarih District, Sergai Regency. This means that the hypothesis in this study is accepted, as evidenced by the value of $t$ count $>t$ table $(2,143>$ 2,037). Meanwhile, the transparency variable in the financial management of village funds (X2) has a significant influence on the performance of village government in Kotarih Baru Village, Kotarih District, Sergai Regency. This means that the hypothesis in this study is accepted, as evidenced by the value of $t$ count $>t$ table $(2.173>2,037)$.

2. Simultaneously, the accountability variable (X1) and the transparency of village fund financial management (X2) have a significant influence on the performance of village government in Kotarih Baru Village, Kotarih District, Sergai Regency. This means that the hypothesis in this study is accepted, as evidenced by the calculated $\mathrm{F}$ value $>\mathrm{F}$ table $(18,489>3.29)$.

3. The accountability variable (X1) and the transparency of village fund financial management (X2) were able to contribute to the influence of the village government performance variable by $53.6 \%$. while the remaining $46.4 \%$ is influenced by other variables not examined in this study.

\section{REFERENCES}

Andrianto Nico. 2007. Transparansi dan Akuntabilitas Publik Melalui e-Goverment. Malang: Bayumedia Publishing.

Christa Yunnita Garung. 2020. Pengaruh Akuntabilitas dan Transparansi Terhadap Pengelolaan Alokasi Dana Desa (Add) Dalam Pencapaian Good Governance Pada Desa Manulea, Kecamatan Sasitamean, Kabupaten Malaka. Universitas Nusa Cendana

Duwi Priyatno. 2008. 5 Jam Belajar Olah Data Dengan SPSS 17. Penerbit Andi. Yogyakarta.

Dwiyanto, dkk. 2002. Reformasi Birokrasi Indonesia, Pusat Studi Kependudukan dan Kebijakan. Yogyakarta.

Mardiasmo. 2009. Akuntansi Sektor Publik. Yogyakarta: ANDY Yogyakarta.

Nasirah. 2016. Analisis Transparansi dan Akuntabilitas Pengelolaan Alokasi Dana Desa (studi pada Desa Mulyoagung Kecamatan Dau). Akuntansi, Universitas Muhammdiyah Malang. 
The Influence of Accountability and Transparency of Financial Management of Village Funds on Village Government Performance in Kotarih Baru Village Kotarih District Sergai Regency

Suriana

Novya Nurul Istiqomah. 2017. Analisis Akuntabilitas, Transparansi, Partisipasi Masyarakat dan Pengawasan Pengelolaan Keuangan Desa Terhadap Kinerja Pemerintah Desa di Kabupaten Ngawi. Ilmu Ekonomi, Universitas Brawijaya Malang.

Permendagri Nomor 113. 2014. Tentang Pengelolaan Keuangan Desa.

Rahmanurrasjid Amin. 2008. Akuntabilitas dan Transparansi Dalam Pertanggung Jawaban Pemerintah Daerah Untuk Mewujudkan Pemerintah Yang Baik DI Daerah. Thesis, Semarang. Universitas Diponegoro.

Ros Febrina Nababan. 2020. Pengaruh Akuntabilitas, Sistem Pengendalian Internal Dan Moralitas Individu Terhadap Potensi Kecurangan Dana Desa (Studi Empiris Pada Desa Se-Kabupaten Simalungun).

Serpinner. 2016. Kinerja Pemerintah Desa Dalam Penyelenggaraan Pemerintahan Di Desasempayang Kecamatan Malinau Barat Kabupaten Malinau.

Sosialisasi UU No.32 Tahun 2004 Tentang Pemerintah Daerah. Jakarta: PT RAJAGRAFINDO PERSADA

Sugiyono. 2017. Metode Penelitian Kuantitatif dan Kualitatif. Alfabeta. Bandung

Sutrisno Van Gobel. 2017. Pengaruh Akuntabilitas Dan Transparansi Pengelolaan Keuangan Alokasi Dana Desa (ADD) Terhadap Kinerja Pemerintah Desa se Kecamatan Bolangitang Timur Kabupaten Bolaang Utara. http://eprints.ums.ac.id/56803/3/BAB\%20I.pdf (diakses Jumat, 04 Juni 2021)

Syaiful Bahri. 2018. Metodologi Penelitian Bisnis Lengkap Dengan Teknik Pengolahan Data SPSS. Edisi I. Penerbit CV. Andi Offset. Yogyakarta

Ulum, I. (2010). Akuntansi Sektor Publik. Malang: UMMPRESS

Undang-Undang Republik Indonesia Nomor 6 Tahun 2014 Tentang Desa. 